\title{
Microbiological and clinical characteristics of Streptococcus gallolyticus subsp. pasteurianus infection in China
}

\author{
Yi Li ${ }^{1}$, Xingchun Chen ${ }^{2}$ Zhijun Zhang ${ }^{3}$, Lijun Wang ${ }^{4}$, Junrui Wang ${ }^{5}$, Ji Zeng ${ }^{6}$, Junwen Yang ${ }^{7}$ and Binghuai Lu ${ }^{8,9,10^{*}}$ (D)
}

\begin{abstract}
Background: Infections by Streptococcus gallolyticus subsp. pasteurianus (SGSP) is often underestimated. Herein, the epidemiological features and resistant characteristics of SGSP in mainland China are characterized to enable a better understanding of its role in clinical infections.

Methods: In the present work, 45 SGSP isolates were collected from the samples of bloodstream, urine, aseptic body fluid, and fetal membrane/placenta from patients in 8 tertiary general hospitals of 6 cities/provinces in China from 2011 to 2017. The identification of all isolates was performed using traditional biochemical methods, 16S rRNA and gyrB sequencing, followed by the characterization of their antibiotic resistance profiling and involved genes.

Results: Among 34 non-pregnancy-related patients, 4 (4/34,11.8\%) patients had gastrointestinal cancer, 10 (10/34, 29.4\%) patients had diabetes, and one patient had infective endocarditis. Moreover, 11 cases of pregnant women were associated with intrauterine infection $(9 / 11,81.2 \%)$ and urinary tract infection $(1 / 11,9.1 \%)$, respectively. Except one, all other SGSP isolates were correctly identified by the BD Phoenix automated system. We found that all SGSP isolates were phenotypically susceptible to penicillin, ampicillin, cefotaxime, meropenem, and vancomycin. Forty strains $(40 / 45,88.9 \%)$ were both erythromycin and clindamycin-resistant, belonging to the $C M L S_{B}$ phenotype, and the majority of them carried erm(B) gene (39/40, 97.5\%). Although the $\mathrm{CMLS}_{\mathrm{B}} / \mathrm{erm}(\mathrm{B})$ constituted the most frequently identified phenotype/genotype combination (25/40,62.5\%) among all erythromycin-resistant $\mathrm{CMLS}_{\mathrm{B}}$ isolates, $\operatorname{erm}(\mathrm{B}) / \operatorname{erm}(\mathrm{A})$, $\operatorname{erm}(\mathrm{B}) / \mathrm{mef}(\mathrm{A} / \mathrm{E})$, and $\operatorname{erm}(\mathrm{B}) / \operatorname{erm}(\mathrm{T})$ was detected in 7, 4, and 3 isolates, respectively. Furthermore, 43 strains $(43 / 45,95.6 \%)$ were tetracycline-resistant, and out of these, 39 strains (39/45, 86.7\%) carried tet $(\mathrm{L}), 27(27 / 45,60.0 \%)$ strains carried tet $(\mathrm{O})$, and $7(7 / 45,15.6 \%)$ strains carried tet $(\mathrm{M})$, alone or combined, respectively. All erythromycin-resistant isolates were also resistant to tetracycline.
\end{abstract}

Conclusions: It is important to study and draw attention on SGSP, an underreported opportunistic pathogen targeting immunodeficient populations, notably elderly subjects, pregnant women and neonates.

Keywords: Streptococcus gallolyticus subsp. pasteurianus, Antibiotic resistance, Intrauterine infection

\section{Background}

Streptococcus gallolyticus subsp. pasteurianus (SGSP), formerly known as S. bovis biotype II/2 [1] and is one member of Group D streptococci, is a cause and a potential pathogen of bacteremia and infective endocarditis

\footnotetext{
* Correspondence: zs25041@126.com

${ }^{8}$ Laboratory of Clinical Microbiology and Infectious Diseases, Department of Pulmonary and Critical Care Medicine, China-Japan Friendship Hospital, No 2, East Yinghua Road, Chaoyang District, Beijing 100029, China

${ }^{9}$ Center for Respiratory Diseases, China-Japan Friendship Hospital, No 2, East

Yinghua Road, Chaoyang District, Beijing 100029, China

Full list of author information is available at the end of the article
}

(IE), as well as urinary tract infection (UTI), in elderly and immunodeficient people [2-4], septicemia and meningitis in newborns, and as well as intrauterine infection in pregnant woman [5-8]. This species is also associated with gastrointestinal malignancy $[3,9]$. It colonizes the digestive and female genital tract and therefore can lead to UTI and neonatal invasive infection, resembling what happens with group B Streptococcus (S. agalactiae, GBS). However, frequently occurring erroneous identification of SGSP might lead to an underestimation of the real incidence of infections caused by the species $[6,10]$.

(C) The Author(s). 2019 Open Access This article is distributed under the terms of the Creative Commons Attribution 4.0 International License (http://creativecommons.org/licenses/by/4.0/), which permits unrestricted use, distribution, and 
Additionally, the susceptibility of SGSP strains to $\beta$-lactam and vancomycin has remained relatively stable over the past years, while variable resistance rates were observed against clindamycin, erythromycin, tetracycline and levofloxacin $[4,11,12]$.

Considering gradually increased clinical infections caused by SGSP $[10,11]$, the clarification of its clinical features and antibiotic resistance is highly desired and should be valuable for its prevention and treatment. Unfortunately, epidemiological studies on SGSP isolates circulating in mainland China have not been conducted yet. To this end, we retrospectively analyzed SGSP isolates collected from 8 tertiary teaching hospitals in 6 cities/provinces in China from 2011 to 2017, and wanted to properly group these strains into species/subspecies level using traditional biochemical methods and $16 \mathrm{~S}$ rRNA as well as $g y r B$ sequencing to obtain their phenotypic and genotypic antibiotic resistance traits. The clinical and antibiotic resistance features of these SGSP isolates would help to understand the infections caused by the species circulating in China and for decision making in the context of empiric therapy.

\section{Methods}

\section{Sample sources}

Forty-seven non-duplicate isolates that were originally identified as SGSP in line with the new taxonomy criteria $[13,14]$ were recovered from 8 tertiary hospitals in China from 2011 to 2017, namely, Civil Aviation General Hospital (CAGH, Beijing) during 2011-2017, Affiliated Hospital of Inner Mongolia Medical University (Huhehot, Inner Mongolia (Neimenggu) Autonomous region) during 2016-2017, Henan Provincial People's Hospital (Zhengzhou, Henan Province) during 2013-2017, Wuhan PuAi Hospital of Huazhong University of Science and Technology (Wuhan, Hubei Province) during 2014-2016, People's Hospital of Guangxi Zhuang Autonomous Region (Nanning, Guangxi Zhuang Autonomous Region) during 20132017, Beijing Tsinghua Changgung Hospital, Medical Center of Tsinghua University (Beijing) during 20142016, Tai'an City Central Hospital (Tai'an, Shandong Province) in 2016, and Zhengzhou Children's Hospital (Zhengzhou, Henan Province) in 2017.

\section{Phylogenetic analysis of $16 \mathrm{~S}$ rRNA gene}

DNAs were extracted from SGSP stains and subjected to PCR amplification and sequencing using a commercial DNA purification kit (Promega) according to the manufacturer's instructions. The $16 \mathrm{~S}$ rRNA genes from all SGSP strains were amplified with two universal primers (27F and 1492R), and the amplification of the DNA gyrase subunit B $(g y r B)$ gene was performed using primers $\operatorname{gyr} B \mathrm{~F}$ 5' -GAAGTDGTIAARATYACBAAYCG-3' and gyrB R5' -
ACATCDGCATCRGTCAT-3' as described elsewhere [15]. The sequencing of the $16 \mathrm{~S}$ rRNA and gyrB was conducted by Ruibiotech (Beijing, China). The consequent comparison of the respective $16 \mathrm{~S}$ rRNA and $\operatorname{gyr} B$ sequences against those in GenBank was performed using online BLASTn (www.ncbi.nlm.nih.gov/blast). A sequence similarity of 99 and $96 \%$ was used as a "cut-off" value for SGSP species identification [16, 17]. In addition, the phylogenetic tree was generated based on the 16S rRNA gene using the neighbour-joining algorithms using MEGA version 10.0.5 and iTOL v4 (https://itol.embl.de). To this end, the sequences were aligned with reference sequences of SGSP type strain AJ297216.1 that is available in the GenBank database.

\section{Bacterial identification using BD Phoenix automated microbiology system}

All 47 isolates were examined by the department of clinical microbiology of $\mathrm{CAGH}$ for further confirmation based on the new taxonomy. BD Phoenix 100 Automated Microbiology System STREP (SMIC/ID) panel (Becton Dickinson, Sparks, MD, USA) was used as the identification method. The misidentified isolates by $\mathrm{BD}$ Phoenix 100 system, including S. infantarius (now designated as S. infantarius subspecies infantarius) (1 isolate) and Enterococcus faecalis (1 isolate), were excluded for further analysis. Finally, 45 SGSP isolates were included in the subsequent study and the clinical data of the patients are shown in Table 1. Their detailed geographic distribution was shown in Fig. 1.

\section{Phenotypical and genotypical features of antibiotic resistance}

Susceptibility tests against penicillin, cefotaxime, vancomycin, meropenem, erythromycin, clindamycin, and tetracycline were performed using STREP (SMIC/ID) panel. The interpretive criteria for antibiotic susceptibility test (AST) were according to the Clinical and Laboratory Standards Institute (CLSI, 2017) for Streptococcus spp. viridans group.

Strains that showed resistant to erythromycin and tetracycline were also analyzed by PCR using conditions as described previously $[1,18]$, to examine the presence of antibiotic resistance genes, which are commonly found among the isolates of $S$. bovis group, including $\operatorname{erm}(\mathrm{A}), \operatorname{erm}(\mathrm{B}), \operatorname{erm}(\mathrm{T}), \operatorname{mef}(\mathrm{A} / \mathrm{E}), \operatorname{tet}(\mathrm{K})$, $\operatorname{tet}(\mathrm{L}), \operatorname{tet}(\mathrm{M})$ and $\operatorname{tet}(\mathrm{O})$.

\section{Statistical analysis}

In the study, MIC50 and MIC90 are defined as the MICs of a given agent that inhibits the growth of 50 and $90 \%$ of the isolates, respectively. MIC data of each antibiotic were recorded and analyzed by WHONET 5.6 software, and MIC50 and MIC90 were also calculated. Furthermore, the 
Table 1 Demographic and clinical features of 45 isolates of Streptococcus gallolyticus subsp. pasteurianus circulating in mainland

\begin{tabular}{|c|c|c|c|c|c|c|c|}
\hline Infection types & Gender & Age & Sources & Underlying diseases & Polymicrobial & City/Province & $\begin{array}{l}\text { Year of } \\
\text { isolation }\end{array}$ \\
\hline \multicolumn{8}{|c|}{ Non-pregnancy-related infections } \\
\hline $\begin{array}{l}\text { Abdominal } \\
\text { infection }\end{array}$ & Female & $41-60$ & Ascitic fluid & Choledochal cyst & No & Beijing & 2016 \\
\hline Bacteremia(13) & $\begin{array}{l}\text { Female(4), } \\
\text { Male(9) }\end{array}$ & $\begin{array}{l}\leq 20,21- \\
40(2) \\
41-60(2) \\
>60(8)\end{array}$ & Blood (13) & $\begin{array}{l}\text { Hematuria, aplastic anemia, hematopoietic } \\
\text { stem cell transplantation, endometrial } \\
\text { carcinoma/colon cancer, fatty liver, } \\
\text { cholecystitis, liver cancer, bone pain, } \\
\text { abdominal pain, diabetes(3), ALL(2). }\end{array}$ & $\begin{array}{l}\text { Enterococcus } \\
\text { faecalis, } \\
\text { MRSA. }\end{array}$ & $\begin{array}{l}\text { Henan(2), } \\
\text { Guangxi(5), } \\
\text { Hubei(3), } \\
\text { Shangdong, } \\
\text { Neimenggu(2). }\end{array}$ & $\begin{array}{l}\text { 2014(3), } \\
\text { 2015(2), } \\
\text { 2016(5), } \\
2017(3)\end{array}$ \\
\hline $\begin{array}{l}\text { Bacteremia/ } \\
\text { infective } \\
\text { endocarditis }\end{array}$ & Male & $41-60$ & Blood & & No & Guangxi & 2015 \\
\hline Biliary infection & Female & $>60$ & Bile & Malignant bile duct tumor & No & Beijing & 2013 \\
\hline $\begin{array}{l}\text { Intra-abdominal } \\
\text { infection }\end{array}$ & Male & $>60$ & $\begin{array}{l}\text { Abdominal } \\
\text { puncture fluid }\end{array}$ & & No & Hubei & 2014 \\
\hline Meningitis & Male & $\leq 20$ & CSF & $\begin{array}{l}\text { Anemia, pneumonia, congenital } \\
\text { heart disease }\end{array}$ & No & Henan & 2017 \\
\hline $\begin{array}{l}\text { Peripancreatic } \\
\text { abscess }\end{array}$ & Female & $41-60$ & $\begin{array}{l}\text { Peripancreatic } \\
\text { drainage }\end{array}$ & Pancreatic tumor & No & Beijing & 2015 \\
\hline UTI(15) & $\begin{array}{l}\text { Female } \\
\text { (10), Male } \\
\text { (5) }\end{array}$ & $\begin{array}{l}21-40(2), \\
>60(13)\end{array}$ & Urine (15) & $\begin{array}{l}\text { Diabetes (7), hematuria, left renal calculus, } \\
\text { hydronephrosis. }\end{array}$ & & $\begin{array}{l}\text { Beijing(2), } \\
\text { Guangxi(5), } \\
\text { Henan(5), } \\
\text { Shangdong, } \\
\text { Henan (2). }\end{array}$ & $\begin{array}{l}2011, \\
2012(2), \\
2013(2), \\
2014, \\
2016(3), \\
2017(6)\end{array}$ \\
\hline \multicolumn{8}{|c|}{ Pregnancy-related infections } \\
\hline Bacteremia & Female & $21-40$ & Blood & Delivery & No & Hubei & 2014 \\
\hline $\begin{array}{l}\text { Intrauterine } \\
\text { infection(7) }\end{array}$ & $\begin{array}{l}\text { Female } \\
\text { (7) }\end{array}$ & $21-40(7)$ & $\begin{array}{l}\text { Fetal } \\
\text { membrane (3), } \\
\text { Fetal } \\
\text { membrane/ } \\
\text { placenta (4). }\end{array}$ & $\begin{array}{l}\text { Premature delivery, post-cesarean delivery, } \\
\text { delivery (5) }\end{array}$ & No & $\begin{array}{l}\text { Beijing(6), } \\
\text { Guangxi }\end{array}$ & $\begin{array}{l}\text { 2011, 2012, } \\
\text { 2013, 2014(2), } \\
\text { 2015(2) }\end{array}$ \\
\hline $\begin{array}{l}\text { Intrauterine } \\
\text { infection/ } \\
\text { bacteremia(2) }\end{array}$ & $\begin{array}{l}\text { Female } \\
\text { (2) }\end{array}$ & $21-40(2)$ & $\begin{array}{l}\text { Fetal } \\
\text { membrane/ } \\
\text { blood (2) }\end{array}$ & Post-cesarean delivery & MRSA & $\begin{array}{l}\text { Beijing, } \\
\text { Guangxi }\end{array}$ & 2012, 2017 \\
\hline UTI & Female & $21-40$ & Urine & & No & Guangxi & 2017 \\
\hline
\end{tabular}

$F$ female, $M$ male, CSF cerebrospinal fluid, UTI urinary tract infection, indicating symptomatic patients with bacteriuria, ALL Acute Lymphocytic Leukemia, MRSA methicillin-resistant Staphylococcus aureus; Number in parentheses represents strains, and no number signified only one strain was detected

distribution of SGSP, as well as ages and infection types, was determined by using GraphPad Prism version 8.0.1.

\section{Results}

\section{Clinical data}

In the present study, the clinical data of these 45 patients with SGSP infections were reviewed and shown in Table 1 and Figs. 2 and 3. The majority of these patients were women $(28 / 45,62.2 \%)$. They were aged from 83 days to 87 years. There are $34(75.6 \%)$ patients were non-pregnant, with an average age of 67 years old. Furthermore, the 45 SGSP isolates were obtained from bloodstream (17 cases, $37.8 \%, 2$ cases were concurrently isolated from fetal membrane), urine (16 cases, $35.6 \%$ ), bile ( 1 case, $2.2 \%$ ), ascitic fluid (1 case, 2.2\%), abdominal puncture fluid (1 case,
$2.2 \%$ ), peripancreatic drainage (1 case, $2.2 \%$ ), peritoneal fluid (1 case, $2.2 \%$ ), cerebrospinal fluid (CSF, 1 case, $2.2 \%$ ) and fetal membrane/placenta (9 cases, 20.0\%).

Among 34 non-pregnancy-related subjects, UTI and bacteremia accounted for $44.1 \%$ (15 cases) and $41.1 \%$ (14 cases), respectively (Fig. 3). The gender distribution was evenly distributed at a ratio of 1:1 (50\%:50\%). The majority of UTI cases occurred in patients over 60 years $(13 / 16$, $81.3 \%)$. Overall, 3 episodes out of 17 bacteremias were polymicrobial, where SGSP was simultaneously detected with Methicillin-resistant Staphylococcus aureus (MRSA) and Enterococcus faecalis.

Furthermore, in 34 non-pregnant patients, some underlying conditions had a higher prevalence: $10 \mathrm{pa}$ tients (29.4\%) had diabetes, 4 patients (11.8\%) had 


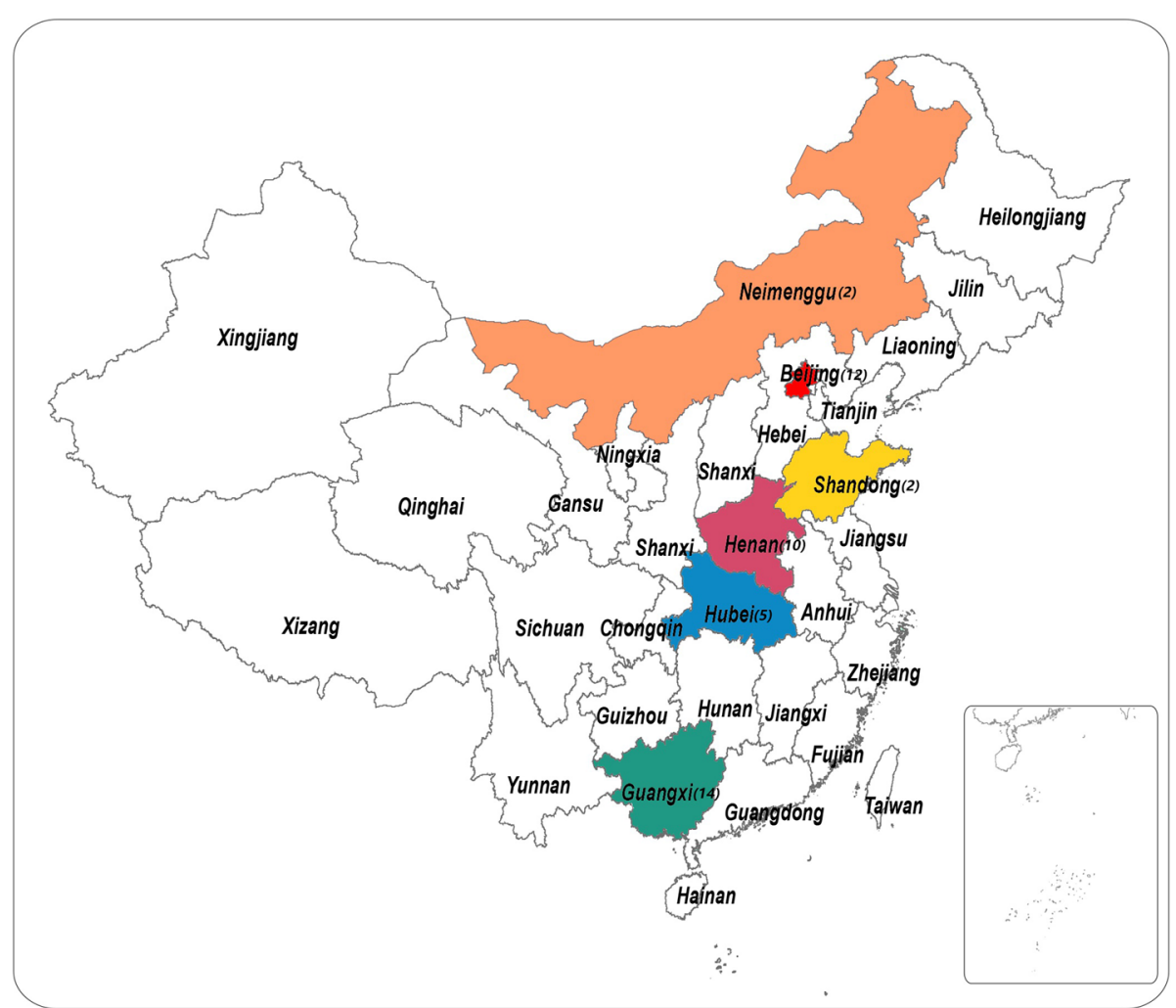

Fig. 1 Geographical locations and numbers of Streptococcus gallolyticus subsp. pasteurianus (SGSP) isolates. The colored provinces represent where SGSP strains were isolated, with the number of isolates shown in brackets

presented with gastrointestinal cancers, and 1 patient (2.2\%) had IE. One case was meningitis in a preterm male infant with late-onset infection (in his $83^{\text {rd }}$ day after born). This patient was born at $29^{+2}$ weeks with a birth weight of $1.45 \mathrm{~kg}$. Moreover, 11 cases were associated with intrauterine infection (7 cases), bacteremia (1 case), or both (2 cases) in pregnancy-related infections.

\section{Strain identification and phylogenetic analysis of the $16 \mathrm{~S}$ rRNA gene}

All 45 isolates were positive for Streptococcus Lancefield antigen $\mathrm{D}$ grouping sera as examined by latex agglutination test.
Initial identification by the automated Phoenix system revealed that all isolates belonged to $S$. bovis biotype II. Nucleotide sequencing of $16 \mathrm{~S}$ rRNA amplicons classified all S. bovis biotype II isolates as SGSP. Furthermore, $\operatorname{gyr} B$ sequencing also identified the isolates as $S$. pasteurianus. The phylogenetic analysis of the $16 \mathrm{~S}$ rRNA gene $(1422 \mathrm{bp})$ was performed by the neighbour-joining method between the 45 SGSP strains and the reference strain of SGSP species (Fig. 4) [19].

\section{Antibiotic-resistant phenotypes and genotypes}

Antimicrobial susceptibility results are shown in Table 2. All the isolates were phenotypically susceptible to

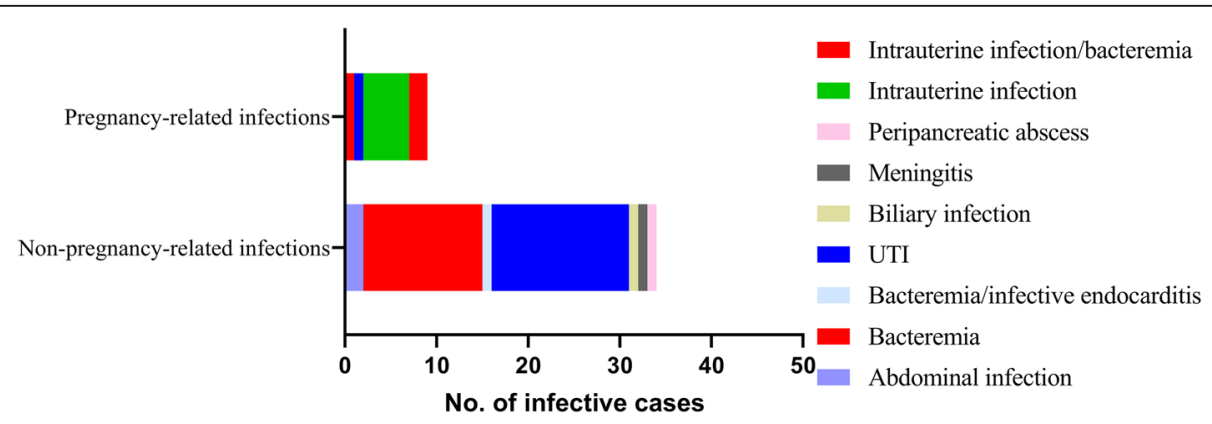

Fig. 2 Distribution of the 45 strains of Streptococcus gallolyticus subsp. pasteurianus (SGSP) in different infections 


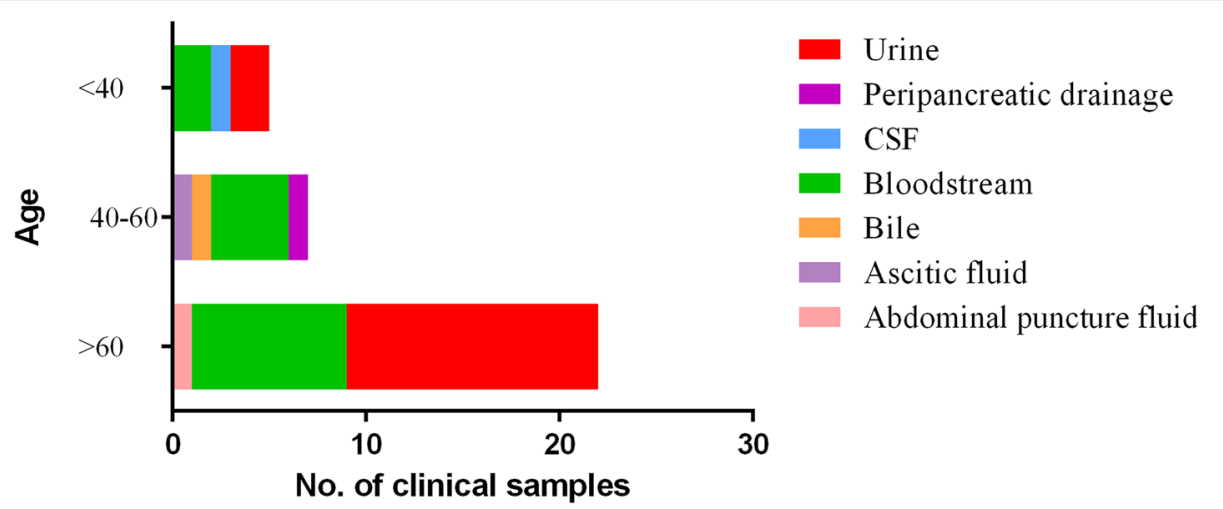

Fig. 3 Relationship between infection sources and ages in 34 cases of non-pregnancy-related infections caused by Streptococcus gallolyticus subsp. pasteurianus (SGSP)

penicillin, ampicillin, cefotaxime, meropenem, and vancomycin. Moreover, 41 strains (91.1\%) showed a simultaneous resistance to erythromycin and clindamycin, and thus classified as $\mathrm{CMLS}_{\mathrm{B}}$ phenotype. All erythromycin-resistant isolates carried at least an $\operatorname{erm}(\mathrm{B})$ gene, except KT478 strain, which was collected from peripancreatic abscess in a 57-year female, and harbored mef(A/ E). No $M$ phenotype or inducible $M_{L} S_{B}$ was detected. Among all erythromycin-resistant $\mathrm{CMLS}_{\mathrm{B}}$ isolates,
$\mathrm{cMLS}_{\mathrm{B}} / \operatorname{erm}(\mathrm{B})$ phenotype/genotype was the most frequently identified combination (25 out of 40 strains, $62.5 \%)$, while $\operatorname{erm}(\mathrm{B}) / \operatorname{erm}(\mathrm{A}), \operatorname{erm}(\mathrm{B}) / m e f(\mathrm{~A} / \mathrm{E})$, and $\operatorname{erm}(\mathrm{B}) / \operatorname{erm}(\mathrm{T})$ were detected in 7,4 , and 3 isolates, respectively, as shown in Table 3.

Moreover, in 43 (95.6\%) out of 45 were tetracycline-resistant strains, 29 strains harbored tet $(\mathrm{L}), 27$ strains tet $(\mathrm{O})$ and 7 strains tet $(\mathrm{M})$, singly or combined. One isolate harbored triple resistance genes of $\operatorname{tet}(\mathrm{O}) / \operatorname{tet}(\mathrm{L}) /$

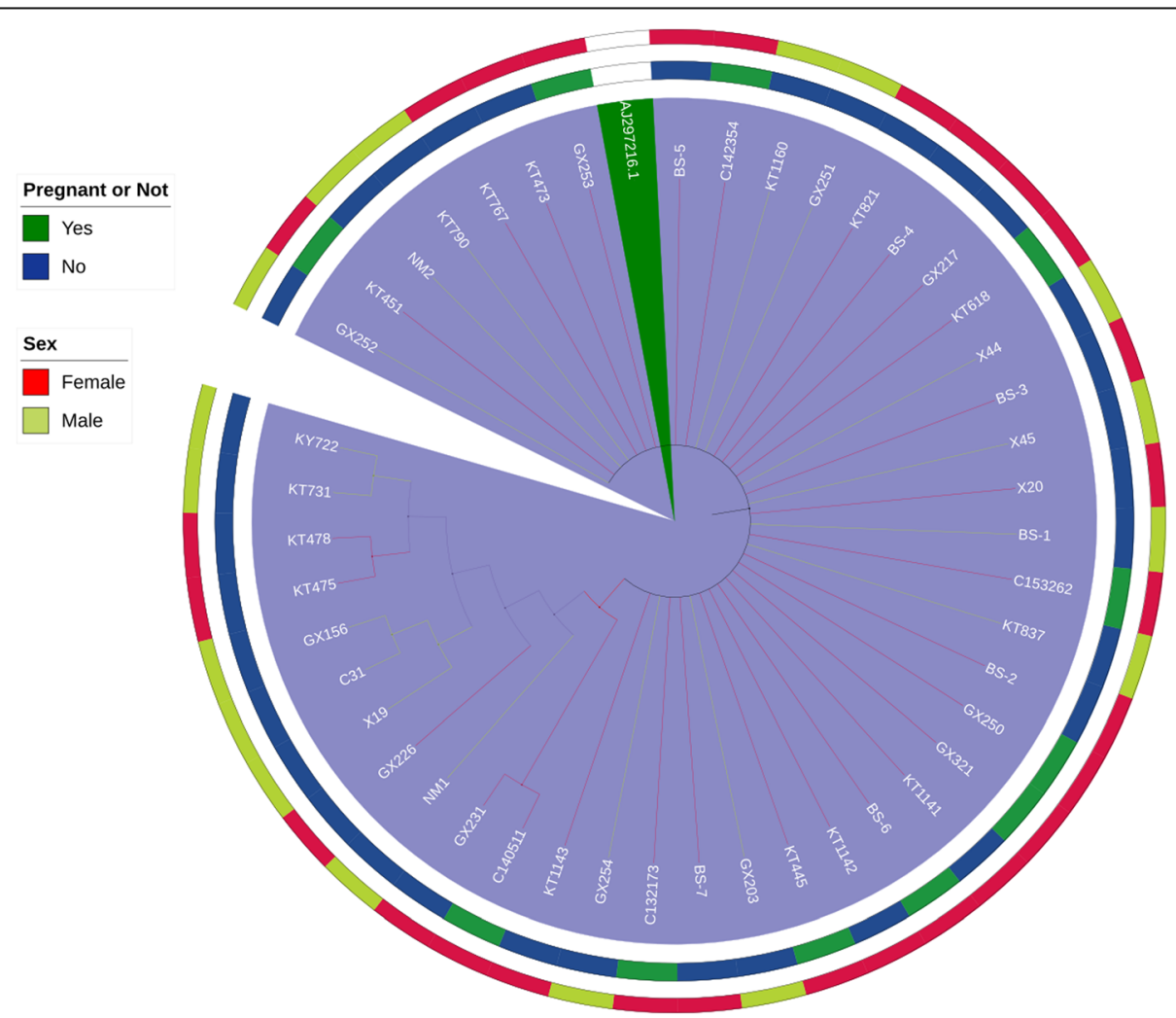

Fig. 4 Phylogenetic tree constructed by the neighbour-joining method based on the nucleotide sequences of the 165 rRNA genes of 45 clinical Streptococcus gallolyticus subsp. pasteurianus (SGSP) strains and one reference strain AJ297216.1 
Table 2 Antimicrobial susceptibilities and minimum inhibitory concentrations of 45 isolates of Streptococcus gallolyticus subsp. pasteurianus

\begin{tabular}{|c|c|c|c|c|c|c|c|}
\hline \multirow[t]{2}{*}{ Antimicrobials } & \multirow[t]{2}{*}{ Breakpoint by CLSI } & \multicolumn{3}{|c|}{ Susceptibility } & \multicolumn{3}{|l|}{ MIC } \\
\hline & & $S(\%)$ & I(\%) & $R(\%)$ & $\begin{array}{l}\mathrm{MIC50} \\
(\mathrm{mg} / \mathrm{l})\end{array}$ & $\begin{array}{l}\mathrm{MIC90} \\
(\mathrm{mg} / \mathrm{l})\end{array}$ & $\begin{array}{l}\text { Range } \\
(\mathrm{mg} / \mathrm{l})\end{array}$ \\
\hline Penicillin & $0.12 / 0.25-2 / 4$ & 100 & 0 & 0 & 0.125 & 0.125 & $<0.03-0.12$ \\
\hline Amoxicillin & $0.25 / 0.5-4 / 8$ & 100 & 0 & 0 & $<0.25$ & $<0.25$ & all $<0.25$ \\
\hline Cefotaxime & $1 / 2 / 4$ & 100 & 0 & 0 & $<0.5$ & $<0.5$ & all $<0.5$ \\
\hline Erythromycin & $0.25 / 0.5 / 1$ & $11.1(5 / 45)$ & 0 & $88.9(40 / 45)$ & $>4$ & $>4$ & $0.0625->4$ \\
\hline Clindamycin & $0.25 / 0.5 / 1$ & $11.1(5 / 45)$ & 0 & $88.9(40 / 45)$ & $>4$ & $>4$ & $0.0625 \sim>4$ \\
\hline Levofloxacin & $2 / 4 / 8$ & $73.3(33 / 45)$ & 15.6(7/45) & $11.1(5 / 45)$ & 2 & 4 & $1 \sim>4$ \\
\hline Moxifloxacin & $1 / 2 / 4$ & $88.9(40 / 45)$ & $2.2(1 / 45)$ & $8.9(4 / 45)$ & 0.5 & 1 & $\leq 0.25 \sim>2$ \\
\hline Tetracycline & $2 / 4 / 8$ & $4.4(2 / 45)$ & $2.2(1 / 45)$ & $93.3(42 / 45)$ & $>8$ & $>8$ & $0.0625 \sim>4$ \\
\hline Linezolid & 2 & 100 & 0 & 0 & $\leq 1$ & 2 & $\leq 1 \sim 2$ \\
\hline Meropenem & 0.5 & 100 & 0 & 0 & $\leq 0.0625$ & $\leq 0.0625$ & $\leq 0.0625$ \\
\hline Vancomycin & 1 & 100 & 0 & 0 & $\leq 0.25$ & $\leq 0.25$ & $\leq 0.25-1$ \\
\hline
\end{tabular}

MIC minimum inhibitory concentration, $S$ susceptible, I intermediate, $R$ resistant, MIC50 minimum inhibitory concentration at which $50 \%$ of isolates were inhibited, MIC90 minimum inhibitory concentration at which $90 \%$ of isolates were inhibited, MIC range range of minimum inhibitory concentration

Table 3 Erythromycin and tetracycline resistance phenotype and genotype in 45 Streptococcus gallolyticus subsp. pasteurianus isolates

\begin{tabular}{|c|c|c|c|c|c|c|c|}
\hline $\begin{array}{l}\text { Erythromycin } \\
\text { phenotype }\end{array}$ & $\begin{array}{l}\text { Clindamycin MIC } \\
(\mu \mathrm{g} / \mathrm{mL})\end{array}$ & $\begin{array}{l}\text { Erythromycin } \\
\text { MIC }(\mu \mathrm{g} / \mathrm{mL})\end{array}$ & $\begin{array}{l}\text { Erythromycin } \\
\text { resistance genotype }\end{array}$ & $\begin{array}{l}\text { Tetracycline } \\
\text { MIC ( } \mu \mathrm{g} / \mathrm{mL})\end{array}$ & $\begin{array}{l}\text { Tetracycline } \\
\text { phenotype }\end{array}$ & $\begin{array}{l}\text { Tetracycline } \\
\text { resistance genotype }\end{array}$ & $\begin{array}{l}\text { No. of } \\
\text { isolates }\end{array}$ \\
\hline $\mathrm{CMLS}_{\mathrm{B}}$ & $>1$ & $>4$ & erm(A)/erm(B) & $>8$ & $\mathrm{R}$ & $\operatorname{tet}(\mathrm{M}) / \operatorname{tet}(\mathrm{L})$ & 2 \\
\hline$C M L S_{B}$ & $>1$ & $>4$ & erm(A)/erm(B) & $>8$ & $\mathrm{R}$ & $\operatorname{tet}(\mathrm{M}) / \operatorname{tet}(\mathrm{O})$ & 1 \\
\hline$C M L S_{B}$ & $>1$ & $>4$ & $\operatorname{erm}(\mathrm{A}) / \operatorname{erm}(\mathrm{B})$ & $>8$ & $\mathrm{R}$ & $\operatorname{tet}(\mathrm{L}) / \operatorname{tet}(\mathrm{O})$ & 1 \\
\hline $\mathrm{CMLS}_{\mathrm{B}}$ & $>1$ & $>4$ & erm(A)/erm(B) & $>8$ & $\mathrm{R}$ & $\operatorname{tet}(\mathrm{O})$ & 3 \\
\hline $\mathrm{CMLS}_{\mathrm{B}}$ & $>1$ & $>4$ & $\operatorname{erm}(\mathrm{B})$ & 4 & 1 & Negative & 1 \\
\hline$C M L S_{B}$ & $>1$ & $>4$ & erm(B) & $>8$ & $\mathrm{R}$ & $\operatorname{tet}(\mathrm{L})$ & 8 \\
\hline$C M L S_{B}$ & $>1$ & $>4$ & $\operatorname{erm}(\mathrm{B})$ & $>8$ & $\mathrm{R}$ & $\operatorname{tet}(\mathrm{L}) / \operatorname{tet}(\mathrm{O})$ & 1 \\
\hline $\mathrm{CMLS}_{\mathrm{B}}$ & $>1$ & $>4$ & $\operatorname{erm}(\mathrm{B})$ & $>8$ & $\mathrm{R}$ & $\operatorname{tet}(\mathrm{M}) / \operatorname{tet}(\mathrm{L})$ & 1 \\
\hline $\mathrm{CMLS}_{\mathrm{B}}$ & $>1$ & $>4$ & erm(B) & $>8$ & $\mathrm{R}$ & $\operatorname{tet}(\mathrm{M}) / \operatorname{tet}(\mathrm{O})$ & 1 \\
\hline$C M L S_{B}$ & $>1$ & $>4$ & $\operatorname{erm}(\mathrm{B})$ & $>8$ & $\mathrm{R}$ & $\operatorname{tet}(\mathrm{O})$ & 7 \\
\hline$C M L S_{B}$ & $>1$ & $>4$ & $\operatorname{erm}(\mathrm{B})$ & $>8$ & $\mathrm{R}$ & $\operatorname{tet}(\mathrm{L}) / \operatorname{tet}(\mathrm{O})$ & 5 \\
\hline$C M L S_{B}$ & $>1$ & $>4$ & erm(B) & $>8$ & R & tet(O)/tet(L)/tet(M) & 1 \\
\hline $\mathrm{CMLS}_{\mathrm{B}}$ & $>1$ & $>4$ & erm(B)/mef(A/E) & $>8$ & $\mathrm{R}$ & $\operatorname{tet}(\mathrm{L})$ & 1 \\
\hline$C M L S_{B}$ & $>1$ & $>4$ & $\operatorname{erm}(\mathrm{B}) / \mathrm{mef}(\mathrm{A} / \mathrm{E})$ & $>8$ & $\mathrm{R}$ & $\operatorname{tet}(\mathrm{O}) / \operatorname{tet}(\mathrm{L})$ & 3 \\
\hline$C M L S_{B}$ & $>1$ & $>4$ & $\operatorname{erm}(\mathrm{B}) / \operatorname{erm}(\mathrm{T})$ & $>8$ & $\mathrm{R}$ & $\operatorname{tet}(\mathrm{M}) / \operatorname{tet}(\mathrm{O})$ & 1 \\
\hline$C M L S_{B}$ & $>1$ & $>4$ & erm(B)/erm(T) & $>8$ & $\mathrm{R}$ & $\operatorname{tet}(\mathrm{O}) / \operatorname{tet}(\mathrm{L})$ & 1 \\
\hline$C M L S_{B}$ & $>1$ & $>4$ & erm(B)/erm(T) & $>8$ & $\mathrm{R}$ & $\operatorname{tet}(\mathrm{L})$ & 1 \\
\hline$C M L S_{B}$ & $>1$ & $>4$ & mef(A/E) & $>8$ & $\mathrm{R}$ & $\operatorname{tet}(\mathrm{O}) / \operatorname{tet}(\mathrm{L})$ & 1 \\
\hline S & 0.125 & $\leq 0.0625$ & Negative & $>8$ & $\mathrm{R}$ & $\operatorname{tet}(\mathrm{L})$ & 1 \\
\hline S & 0.0625 & $\leq 0.0625$ & Negative & $>8$ & $\mathrm{R}$ & $\operatorname{tet}(\mathrm{L})$ & 1 \\
\hline S & 0.0625 & $\leq 0.0625$ & Negative & $>8$ & $\mathrm{R}$ & $\operatorname{tet}(\mathrm{O}) / \operatorname{tet}(\mathrm{L})$ & 1 \\
\hline S & 0.0625 & $\leq 0.0625$ & Negative & $\leq 0.5$ & S & Negative & 2 \\
\hline
\end{tabular}


tet $(\mathrm{M})$ at the same time. No tet $(\mathrm{K})$ gene was identified. Interestingly, all erythromycin-resistant isolates were also resistant to tetracycline, and both tetracycline-sensitive isolates were also sensitive to erythromycin.

\section{Literature review}

To better understand the features of SGSP infections worldwide, we searched MEDLINE database (https:// www.ncbi.nlm.nih.gov/pubmed) for the studies reporting the clinical infections caused by SGSP. Five reports including185 clinical SGSP isolates were included for comparison, and the details were summarized in Table $4[4,11,14,20,21]$.

\section{Discussion}

This work is, to the best of our knowledge, the first comprehensive study on infective SGSP isolates in mainland China. The complexity of S. bovis taxonomy and relatively limited infection reports constrain clinical studies of SGSP, which is thus considered as an underreported opportunistic pathogen [10, 14]. In the present study, we found that 22 out of 34 non-pregnancy-related subjects $(64.7 \%)$ were elderly subjects with ages over 65 years. Interestingly, a study conducted in southern-central Israel reported that $75 \%$ bacteremia by S. bovis was over 65 years [20]. This, together with our data, suggests that elderly people are prone to SGSP infection. Moreover, we also observed that among 15 SGSP isolates (15/ $34,44.1 \%$ non-pregnant subjects) recovered from UTI patients, 10 had diabetes. This observation was in line with a retrospective study in Italy, which reported that among $63.6 \%$ of patients $(14 / 22)$ with UTI caused by SGSP, diabetes was the most common underlying disease $(7 / 22,31.8 \%)$ [4]. Another study in Spain also found that most $S$. bovis group isolates (72\%) causing UTI were SGSP [2]. These observations thus collectively hint that SGSP can be taken as a potential pathogen in UTI, especially in those with diabetes [2]. Additionally, it should be noted that $62.5 \%$ patients (10/16) with SGSP bacteremia were male, demonstrating a correlation between gender and SGSP isolation from the urinary tract, as suggested in another two previous studies [4]. Together, the elderly, pregnant women and the immunodeficient population are the main people who are under the risk of SGSP infection.

Bacteremia caused by SGSP was shown to be associated with malignancy of various parts of the digestive tract, including gastric, pancreatic, hepatobiliary and colorectal cancers [11, 22-25]. In our study, 1 case of malignant bile duct tumor, 1 case of endometrial carcinoma/colon cancer, 1 case of pancreatic tumor and 1 case of liver cancer were identified in non-pregnant-related infections, respectively. It was reported that all S. bovis strains from bile were likely associated with biliary tract malignancy [20], and SGSP was more frequently identified in the bacteremia with a biliary source $(15 / 27$ cases, $55.6 \%$,) than S. infantarius (20/46, 43.5\%) and S. gallolyticus subsp. gallolyticus (SGSG, 2/112, 1.8\%) [23]. It should be noted, in colorectal carcinoma, a lower risk was noticed for SGSP, compared with SGSG at an odds ratio of 7.26 [26]. As a consequence, considering the association between $S$. bovis subspecies and specific pathogenesis, it is thus mandatory for every $S$. viridans organism isolated from the bloodstream to be identified into a species/subspecies level in order to distinguish SGSP from other $S$. bovis group members [4, 10, 22]. Additionally, SGSP bacteremia was observed to be less associated with IE than SGSG $(8 \sim 29 \%$ in SGSP vs $43 \sim 100 \%$ in SGSG), too [22, 26]. Only one case $(1 / 16$, $6.25 \%)$ of SGSP bacteremia was diagnosed with IE in the present study. Another observation was that the hematological diseases, including aplastic anemia (with hematopoietic stem cell transplantation) and acute lymphoblastic leukemia, were detected in two patients in our study, and this has been rarely documented previously [22]. The underlying mechanism remains elusive.

SGSP colonizes asymptomatically in the gastrointestinal and genitourinary tracts in pregnant women, and thus might potentially cause neonatal meningitis and bacteremia $[7,8,27,28]$. There is a very high one-year mortality rate of $58.7 \%$ in SGSP bacteremia [22]. The current study involves 9 cases $(9 / 45,20 \%)$ of intrauterine infections, and 2 cases $(2 / 45,4.4 \%)$ of bacteremia in pregnant women and neonates, hinting that SGSP is an important pathogen of pregnancy-related infection $[8,28-30]$. One case of late-onset meningitis in a preterm male infant is detected in this study. Furthermore, our previous report found one case of intrauterine infection and post-partum bacteremia that was attributed to SGSP providing evidence of a possible portal of entry in cases of maternal or neonatal infection [8]. This potential infective pathway might be confirmed because more similar cases exist in this work. Altogether, we support the hypothesis that SGSP, which is different from other subspecies of S.bovis group, is a potential pathogen of maternal-fetal infection similarly to GBS [8].

Phenotypic variations always limit a correct identification of $S$. bovis species by the use of conventional microbiology and biochemical methods. However, in this study, Phoenix100 system identified most SGSP strains into subspecies level correctly, except the KT445 strain collected from fetal membrane in a 32year female, and that was misidentified as $S$. bovis I (Strep. group D) by Phoenix100, but confirmed as SGSP (S. pasteurianus strain CIP 107122) using 16S rRNA gene. Therefore, it is tempting to conclude that the classical biochemical methods are suitable and sufficient to fulfill clinical purposes. 
Table 4 Summary of the reported cases of clinical infections by Streptococcus gallolyticus subsp. pasteurianus

\begin{tabular}{|c|c|c|c|c|c|c|}
\hline & present study & $1[4]$ & $2[11]$ & $3[14]$ & $4[20]$ & $5[21]$ \\
\hline Number & 45 & $\begin{array}{l}20 \text { patients ( } 22 \\
\text { isolates were } \\
\text { recovered) }\end{array}$ & 126 & 24 & 13 & 2 \\
\hline Study period & 2011-2017 & $\begin{array}{l}\text { May 2010-Jan } \\
2012\end{array}$ & 2000-2012 & $\begin{array}{l}\text { January } 2003 \text { and } \\
\text { January } 2010\end{array}$ & 2004-2010 & 1988-2014 \\
\hline Country/area & China & Italy & Taiwan & Spain & Israel & Spain \\
\hline \multicolumn{7}{|c|}{ Demographic characteristics } \\
\hline $\begin{array}{l}\text { Gender (Male/ } \\
\text { female) }\end{array}$ & $17 / 28$ & $7 / 13$ & $79 / 47$ & NA & $7 / 6$ & $1 / 1$ \\
\hline $\begin{array}{l}\text { Age (mean } \pm \\
\text { SD or median } \\
\text { and } I Q D \text {, years) }\end{array}$ & $67 \pm 22$ & $72 \pm 13$ & $70(55,78)$ & NA & $60 \pm 33$ & 89 and 62 \\
\hline $\begin{array}{l}\text { Age }>65 \\
\text { years }\end{array}$ & $19(42.2 \%)$ & 15 & $76(60 \%)$ & NA & NA & $1(50 \%)$ \\
\hline $\begin{array}{l}\text { Pregnant } \\
\text { women }\end{array}$ & $11(24.4 \%)$ & 0 & NA & NA & $2(15 \%)$ & 0 \\
\hline $\begin{array}{l}\text { Neonates }(< \\
3 \text { months of } \\
\text { age) }\end{array}$ & $1(2.2 \%)$ & 0 & NA & NA & $2(15 \%)$ & 0 \\
\hline $\begin{array}{l}\text { Paediatric } \\
\text { patients (< } \\
18 \text { years) }\end{array}$ & $1(2.2 \%)$ & 0 & $5(4 \%)$ & NA & NA & NA \\
\hline $\begin{array}{l}\text { Infection types/ } \\
\text { source }\end{array}$ & $\begin{array}{l}\text { Bacteremia (17), urine (16), } \\
\text { bile (1), ascitic fluid (1), } \\
\text { abdominal puncture fluid } \\
\text { (1), peripancreatic drainage } \\
\text { (1), peritoneal fluid (1), } \\
\text { CSF(1) and fetal } \\
\text { membrane/placenta (9) }\end{array}$ & $\begin{array}{l}\text { UTI(10), } \\
\text { bacteremia(2), } \\
\text { limb ulcer (1), } \\
\text { bile(3) }\end{array}$ & Bacteremia(126) & Bacteremia(24) & Bacteremia(13) & $\begin{array}{l}\text { Spondylodiscitis/ } \\
\text { paravertebral } \\
\text { abscess (1), } \\
\text { pubicsymphysitis } \\
\text { and UTI(1) }\end{array}$ \\
\hline \multicolumn{7}{|l|}{ Underlying diseases } \\
\hline Diabetes & $10(22.2 \%)$ & $8(40 \%)$ & $43(34 \%)$ & $2(8.3 \%)$ & $2(15 \%)$ & $1(50 \%)$ \\
\hline $\begin{array}{l}\text { Chronic renal } \\
\text { failure }\end{array}$ & NA & $1(5 \%)$ & $22(17 \%)$ & $1(4.2 \%)$ & $3(23 \%)$ & NA \\
\hline Liver disease & NA & $4(20 \%)$ & $53(42 \%)$ & NA & 4(31\%) & NA \\
\hline $\begin{array}{l}\text { Malignancy } \\
\text { (past or active) }\end{array}$ & $4(8.9 \%)$ & 6(30\%) & $68(54 \%)$ & $\begin{array}{l}9(37.5 \% \text {, colonic adenoma } \\
\text { (4); bladder cancer(1); } \\
\text { prostate cancer( } 1) ; \\
\text { pulmonary cancer(1); } \\
\text { mucosa-associated lymph } \\
\text { oid tissue lymphoma (1); } \\
\text { leukemia(1)) }\end{array}$ & $3(23 \%)$ & $\begin{array}{l}\text { Adenoma(1); } \\
\text { prostate } \\
\text { cancer(1) }\end{array}$ \\
\hline $\begin{array}{l}\text { Gastrointestinal } \\
\text { tract tumors }\end{array}$ & $4(8.9 \%)$ & $4(20 \%)$ & $\begin{array}{l}51(40 \%, \\
\text { including colon/ } \\
\text { rectum, stomach, } \\
\text { pancreas, liver, } \\
\text { bile duct). }\end{array}$ & 4(16.7\%) & $4(31 \%)$ & $1(50 \%)$ \\
\hline $\begin{array}{l}\text { Biliary } \\
\text { pathology }\end{array}$ & $1(2.2 \%)$ & $4(20 \%)$ & $\begin{array}{l}9(7 \%, \text { biliary tract } \\
\text { stone) }\end{array}$ & $5(20.8 \%)$ & $2(15 \%)$ & NA \\
\hline Bacteriuria & 16(35.6\%) & $\begin{array}{l}\text { 14(70\%)(50\% } \\
\text { UTI); }\end{array}$ & $2(2 \%)$ & 0 & NA & $1(50 \%)$ \\
\hline Endocarditis & $1(2.2 \%)$ & $2(10 \%)$ & $17(13 \%)$ & $6(25 \%)$ & $3(23 \%)$ & $1(50 \%)$ \\
\hline $\begin{array}{l}\text { Identification } \\
\text { methods }\end{array}$ & $\begin{array}{l}\text { BD Phoenix 100, } 165 \\
\text { rRNA/gyrB sequencing }\end{array}$ & $\begin{array}{l}\text { Phoenix100, } 165 \\
\text { rDNA } \\
\text { sequencing, } \\
\text { MALDI Biotyper } \\
\text { Bruker and Vitek } \\
\text { MS }\end{array}$ & $\begin{array}{l}\text { Vitek automated } \\
\text { system; } 16 \mathrm{~S} \text { rRNA } \\
\text { and sodA genes } \\
\text { and PCR-RFLP } \\
\text { assays of groESL } \\
\text { gene }\end{array}$ & $\begin{array}{l}\text { API } 20 \text { Strep system, } \\
\text { semiautomated Wider } \\
\text { system, 16S rRNA and } \\
\text { sodA PCR, Bruker Biotyper } \\
\text { MALDI-TOF MS }\end{array}$ & $\begin{array}{l}\text { PCR-RFLP/ } \\
\text { Vitek } 2\end{array}$ & $\begin{array}{l}\text { API } 20 \text { Strep } \\
\text { system/Vitek 2, } \\
16 \mathrm{~S} \text { rRNA/sodA } \\
\text { sequencing }\end{array}$ \\
\hline
\end{tabular}


Table 4 Summary of the reported cases of clinical infections by Streptococcus gallolyticus subsp. pasteurianus (Continued)

\begin{tabular}{|c|c|c|c|c|c|c|}
\hline & present study & $1[4]$ & $2[11]$ & $3[14]$ & $4[20]$ & $5[21]$ \\
\hline Number & 45 & $\begin{array}{l}20 \text { patients ( } 22 \\
\text { isolates were } \\
\text { recovered) }\end{array}$ & 126 & 24 & 13 & 2 \\
\hline \multicolumn{7}{|c|}{ Antibiotic susceptibility rate (median, $\mu \mathrm{g} / \mathrm{mL}$ )(susceptibility rate(\%)) } \\
\hline penicillin & $0.125(100)$ & NA(100) & $0.06(100)$ & NA (NA) & $0.06(100)$ & NA (NA) \\
\hline cefatriaxone & $<0.5(100)$ & $\begin{array}{l}\text { NA(100\% to } \\
\text { cefotaxime) }\end{array}$ & $0.12(100)$ & NA (NA) & $0.09(100)$ & $N A(N A)$ \\
\hline erythromycin & $\begin{array}{l}>4(11.1 \%, \operatorname{erm}(\mathrm{B}) / \operatorname{erm}(\mathrm{A}) \text {, } \\
\text { erm(B)/mef(A/E), and } \\
\text { erm(B)/erm(T) were } \\
\text { detected in } 7,4 \text {, and } 3 \\
\text { isolates, respectively). }\end{array}$ & $\begin{array}{l}\mathrm{NA}(68.2 \% \text {, all } \\
\text { resistant isolates } \\
\text { belonged to the } \\
\mathrm{CMLS}_{\mathrm{B}} \text { phenotype, } \\
\text { carried erm }(\mathrm{B})) \text {. }\end{array}$ & $32(37 \%)$ & $0.5(62.5 \%)$ & NA (NA) & NA (NA) \\
\hline clindamycin & $>4(11.1 \%)$ & NA(68.2\%) & $0.06(39 \%)$ & $0.5(75 \%)$ & NA (NA) & NA (NA) \\
\hline levofloxacin & 2(73.3\%) & NA (NA) & $2(82 \%)$ & 0.5(91.7\%) & NA (NA) & $N A(N A)$ \\
\hline vancomycin & $\leq 0.25$ & NA (NA) & $0.5(100 \%)$ & $N A(N A)$ & NA (NA) & NA (NA) \\
\hline $\begin{array}{l}\text { tetracycline } \\
(\mu \mathrm{g} / \mathrm{mL})\end{array}$ & $\begin{array}{l}>8((4.4 \%), 39 \text { strains } \\
\text { carried tet }(\mathrm{L}), 27 \text { tet }(\mathrm{O}) \text {, and } \\
7 \text { tet( }(\mathrm{M}) \text {, alone or } \\
\text { combined, respectively.) }\end{array}$ & $\begin{array}{l}\mathrm{NA}(31.8 \% \text {, the } \\
\text { resistant isolates } \\
\text { carried tet }(\mathrm{O})(11) \\
\text { and tet(M)(4). }\end{array}$ & NA (NA) & NA (NA) & NA (NA) & $N A(N A)$ \\
\hline
\end{tabular}

NA Not available, CSF Cerebrospinal fluid, UTI urinary tract infection; Number in parentheses represents strains, and no number signified only one strain was detected

Treatment of SGSP infection, especially in meningitis, often includes intravenous penicillin, ampicillin and cefotaxime administration [7]. Considering all SGSP isolates were susceptible to penicillin [2], cefotaxime, vancomycin, meropenem, and chloramphenicol, the narrowest spectrum antibiotic penicillin should be considered as the drug of choice. In line with our results, this antibiotic choice should be recommended in mainland China. Furthermore, SGSP resistance rates varied for clindamycin, erythromycin, tetracycline and levofloxacin [11]. In our study, most SGSP isolates $(40 / 45,88.9 \%)$ simultaneously exhibited resistance to macrolides and clindamycin, dramatically higher than that of $31.8 \%$ in Italy [4] and 37.5\% in Spain [14]. The resistance of SGSP isolates was due to the presence of either $\operatorname{erm}(\mathrm{B})$ and $\operatorname{erm}(\mathrm{T})$ genes or to a lesser extent mef(A/E) gene [4, 31, 32]. All erythromycin-resistant isolates in this study also displayed resistance to clindamycin, with the $\mathrm{CMLS}_{\mathrm{B}}$ resistance phenotype caused mainly by the erm(B) gene. While efflux-encoding mef(A/E) genes were only detectable in 5 isolates, singly ( 1 case) or combined with $\operatorname{erm}(\mathrm{B})$ (4 cases), which is different from previous reports in which $\operatorname{erm}(\mathrm{T})$ was found to be responsible for most macrolide resistance [12, 31]. Among the reported SGSP strains in Italy, 68.2\% (15/22) were tetracycline-resistant, and most of them harbored either tet $(\mathrm{O})$ (10 cases) or tet $(\mathrm{M})$ (4 cases) [4]. In the current study, however, 93.3\% strains were tetracycline-resistant, most carried tet $(\mathrm{L})$ gene, and less carried $\operatorname{tet}(\mathrm{O})$ and $\operatorname{tet}(\mathrm{M})$ genes, singly or combined, while no isolate carried tet $(\mathrm{K})$ gene. This discrepancy might be explained by geographic and/or species differences. Furthermore, all erythromycin-resistant isolates were also resistant to tetracycline, similar to a previous study [4] . Taken together, these findings demonstrated that antibiotic resistance was widespread among SGSP clinical isolates, thus representing a serious problem particularly when the emerging infection rates are considered, especially in those allergic to $\beta$-lactam antibiotics.

\section{Conclusions}

In summary, this study on infective SGSP isolates circulating in mainland China underscores the clinical importance of this microorganism and provides valuable information about clinical features and epidemiological characteristics of SGSP. It is important to draw attention to this underreported opportunistic pathogen targeting immunodeficient populations, notably elderly subjects, pregnant women and neonates.

\section{Abbreviations}

IE: infective endocarditis; MRSA: Methicillin-resistant Staphylococcus aureus; SGSG: Streptococcus gallolyticus subsp. gallolyticus; SGSP: Streptococcus gallolyticus subsp. pasteurianus; UTI: urinary tract infection

\section{Acknowledgments}

Not applicable.

\section{Authors' contributions}

YL, XCC, ZJZ, LJW, JRW, JZ, JWY, and BHL isolated bacteria and performed the laboratory measurements. $\mathrm{YL}$ and $\mathrm{BHL}$ made substantial contributions to 
conception and design. BHL drafted and revised the manuscript. All authors read and approved the final manuscript.

\section{Funding}

This study was supported by National Key Research and Development Program of China (Grant 2018YFC1200100 and No. 2018YFC1200102) and Beijing Municipal Science \&Technology Commission, PR China (No. Z171100001017118) for specimen's collection and analysis. The funding bodies had no role in the design of the study and collection, analysis, and interpretation of data and in writing the manuscript.

\section{Availability of data and materials}

I can confirm I have included a statement regarding data and material availability in the declaration section of my manuscript. All the data and material involved in the current study are available from the corresponding author on reasonable request.

\section{Ethics approval and consent to participate}

The institutional review boards at the Henan provincial people's hospital approved the study protocol. The written informed consent from participants was exempted, because it focused only on the epidemical features of SGSP strains, and the privacy of involved subjects was not affected

\section{Consent for publication}

Not applicable.

\section{Competing interests}

I confirm that I have read BioMed Central's guidance on competing interests. The authors declare that they have no competing interests.

\section{Author details}

'Department of Laboratory Medicine, Henan Provincial People's Hospital, Zhengzhou 450003, China. Department of Laboratory Medicine, People's Hospital of Guangxi Zhuang Autonomous Region, Nanning 530021, China. 32Department of Laboratory Medicine, Tai'an City Central Hospital (Tai'an), Shandong 271016, China. ${ }^{4}$ Department of Laboratory Medicine, Beijing Tsinghua Chang Gung Hospital, Tsinghua University, Beijing 102218, China. ${ }^{5}$ Department of clinical laboratory, Affiliated hospital of Inner Mongolia medical university, Hohhot 010050, China. ${ }^{6}$ Department of Laboratory Medicine, Wuhan Pu Ai Hospital of Huazhong University of Science and Technology, Wuhan 430034, China. ${ }^{7}$ Department of Laboratory Medicine, Zhengzhou children's hospital, Zhengzhou 450018, China. ${ }^{8}$ Laboratory of Clinical Microbiology and Infectious Diseases, Department of Pulmonary and Critical Care Medicine, China-Japan Friendship Hospital, No 2, East Yinghua Road, Chaoyang District, Beijing 100029, China. ${ }^{9}$ Center for Respiratory Diseases, China-Japan Friendship Hospital, No 2, East Yinghua Road Chaoyang District, Beijing 100029, China. ${ }^{10}$ National Clinical Research Center of Respiratory Diseases, No 2, East Yinghua Road, Chaoyang District, Beijing 100029, China.

\section{Received: 18 April 2019 Accepted: 27 August 2019}

\section{Published online: 09 September 2019}

\section{References}

1. Tsai JC, Hsueh PR, Chen HJ, Tseng SP, Chen PY, Teng LJ. The erm(T) gene is flanked by IS1216V in inducible erythromycin-resistant Streptococcus gallolyticus subsp. pasteurianus. Antimicrob Agents Chemother. 2005;49(10):4347-50

2. Matesanz M, Rubal D, Iñiguez I, Rabuñal R, García-Garrote F, Coira A, GarcíaPaís MJ, Pita J, Rodriguez-Macias A, López-Álvarez MJ, Alonso MP, Corredoira J. Is Streptococcus bovis a urinary pathogen? Eur J Clin Microbiol Infect Dis. 2015:34(4):719-25.

3. Takamura N, Kenzaka T, Minami K, Matsumura M. Infective endocarditis caused by Streptococcus gallolyticus subspecies pasteurianus and colon cancer. BMJ Case Rep. 2014;2014. https://doi.org/10.1136/bcr-2013-203476.

4. Gherardi G, Palmieri C, Marini E, Pompilio A Crocetta V. Di Bonaventura G, Creti $R$, Facinelli B. Identification, antimicrobial resistance and molecular characterization of the human emerging pathogen Streptococcus gallolyticus subsp. pasteurianus. Diagn Microbiol Infect Dis. 2016;86(4):329-35.
5. Hede SV, Olarte L, Chandramohan L, Kaplan SL, Hulten KG. Streptococcus gallolyticus subsp. pasteurianus infection in twin infants. J Clin Microbiol. 2015;53(4):1419-22.

6. Tarakci N, Turk Dagi H, Ugur AR, Tuncer I, Tastekin A. Late-onset Streptococcus pasteurianus sepsis in a preterm baby in a neonatal intensive care unit. Türk Pediatri Arşivi. 2014;49(2):157-9.

7. Park JW, Eun SH, Kim EC, Seong MW, Kim YK. Neonatal invasive Streptococcus gallolyticus subsp. pasteurianus infection with delayed central nervous system complications. Korean J Pediatrics. 2015;58(1):33-6.

8. Binghuai LWS, Xinxin L. Intrauterine infection and post-partum bacteraemia due to Streptococcus gallolyticus subsp. pasteurianus. J Med Microbiol. 2013;62(62):1617-9.

9. Chand G, Shamban L, Forman A, Sinha P. The Association of Streptococcus gallolyticus subspecies pasteurianus bacteremia with the detection of premalignant and malignant colonic lesions. Case Rep Gastrointest Med 2016;2016:7815843.

10. Dekker JP, Lau AF. An update on the Streptococcus bovis group: classification, identification, and disease associations. J Clin Microbiol. 2016;54(7):1694-9.

11. Sheng WH, Chuang YC, Teng LJ, Hsueh PR. Bacteraemia due to Streptococcus gallolyticus subspecies pasteurianus is associated with digestive tract malignancies and resistance to macrolides and clindamycin. J Infect. 2014;69(2):145-53

12. Teng $L$, Hsueh PR, Ho SW, Luh KT. High prevalence of inducible erythromycin resistance among Streptococcus bovis isolates in Taiwan. Antimicrob Agents Chemother. 2001;45(12):3362-5.

13. Schlegel L, Grimont F, Ageron E, Grimont PA, Bouvet A. Reappraisal of the taxonomy of the Streptococcus bovis/Streptococcus equinus complex and related species: description of Streptococcus gallolyticus subsp. gallolyticus subsp. nov., S. gallolyticus subsp. macedonicus subsp. nov. and S. gallolyticus subsp. pasteurianus subsp. nov. Int J Syst Evol Microbiol. 2003; 53(Pt 3):631-45.

14. Romero B, Morosini Ml, Loza E, Rodriguez-Banos M, Navas E, Canton R, Campo RD. Reidentification of Streptococcus bovis isolates causing bacteremia according to the new taxonomy criteria: still an issue? J Clin Microbiol. 2011;49(9):3228-33.

15. Maeda Y, Murayama M, Goldsmith CE, Coulter WA, Mason C, Millar BC Dooley JS, Lowery CJ, Matsuda M, Rendall JC, et al. Molecular characterization and phylogenetic analysis of quinolone resistancedetermining regions (QRDRs) of gyrA, gyrB, parC and parE gene loci in viridans group streptococci isolated from adult patients with cystic fibrosis. J Antimicrob Chemother. 2011;66(3):476-86.

16. Galloway-Peña J, Sahasrabhojane P, Tarrand J, Han XY, Shelburne SA. GyrB polymorphisms accurately assign invasive viridans group streptococcal species. J Clin Microbiol. 2014;52(8):2905-12.

17. Zhou M, Yang Q, Kudinha T, Zhang L, Xiao M, Kong F, Zhao Y, Xu YC. Using matrix-assisted laser desorption ionization-time of flight (MALDI-TOF) complemented with selected $16 \mathrm{~S}$ rRNA and gyrB genes sequencing to practically identify clinical important Viridans group streptococci (VGS). Front Microbiol. 2016:7:1328.

18. Lu B, Fang Y, Fan Y, Chen X, Wang J, Zeng J, Li Y, Zhang Z, Huang L, Li H, et al. High prevalence of macrolide-resistance and molecular characterization of Streptococcus pyogenes isolates circulating in China from 2009 to 2016. Front Microbiol. 2017:8:1052

19. Kumar S, Stecher G, Li M, Knyaz C, Tamura K. MEGA X: molecular evolutionary genetics analysis across computing platforms. Mol Biol Evol. 2018;35(6):1547-9.

20. Lazarovitch T, Shango M, Levine M, Brusovansky R, Akins R, Hayakawa K, Lephart PR, Sobel JD, Kaye KS, Marchaim D. The relationship between the new taxonomy of Streptococcus bovis and its clonality to colon cancer, endocarditis, and biliary disease. Infection. 2013:41(2):329-37.

21. Garcia-Pais MJ, Rabunal R, Armesto V, Lopez-Reboiro M, Garcia-Garrote F, Coira A, Pita J, Rodriguez-Macias Al, Lopez-Alvarez MJ, Alonso MP, et al. Streptococcus bovis septic arthritis and osteomyelitis: a report of 21 cases and a literature review. Semin Arthritis Rheum. 2016:45(6):738-46.

22. Marmolin ES, Hartmeyer GN, Christensen JJ, Nielsen XC, Dargis R, Skov MN, Knudsen E, Kemp M, Justesen US. Bacteremia with the bovis group streptococci: species identification and association with infective endocarditis and with gastrointestinal disease. Diagn Microbiol Infect Dis. 2016;85(2):239-42

23. Corredoira J, Alonso MP, Garcia-Garrote F, Garcia-Pais MJ, Coira A, Rabunal R Gonzalez-Ramirez A, Pita J, Matesanz M, Velasco D, et al. Streptococcus 
bovis group and biliary tract infections: an analysis of 51 cases. Clin Microbiol Infect. 2014;20(5):405-9.

24. Su Y, Miao B, Wang H, Wang C, Zhang S. Splenic abscess caused by Streptococcus gallolyticus subsp. pasteurianus as presentation of a pancreatic cancer. J Clin Microbiol. 2013;51(12):4249-51.

25. Alvarez A, Garcia CJ, Jia Y, Boman D, Zuckerman MJ. Streptococcus bovis bacteremia: association with gastrointestinal and liver disease in a predominantly Hispanic population. South Med J. 2015;108(7):425-9.

26. Boleij A, van Gelder MM, Swinkels DW, Tjalsma H. Clinical importance of Streptococcus gallolyticus infection among colorectal cancer patients: systematic review and meta-analysis. Clin Infect Dis. 2011;53(9):870-8.

27. Saegeman V, Cossey V, Loens K, Schuermans A, Glaser P. Streptococcus Gallolyticus Subsp. Pasteurianus infection in a neonatal intensive care unit. Pediatr Infect Dis J. 2016;35(11):1272-5.

28. Nagamatsu M, Takagi T, Ohyanagi T, Yamazaki S, Nobuoka S, Takemura H, Akita H, Miyai M, Ohkusu K. Neonatal meningitis caused by Streptococcus gallolyticus subsp. pasteurianus. J Infect Chemother. 2012;18(2):265-8.

29. Takahashi Y, Ishiwada N, Tanaka J, Okusu K, Ichimura S, Hishiki H, Ota S, Kohno Y. Streptococcus gallolyticus subsp. pasteurianus meningitis in an infant. Pediatr Int. 2014;56(2):282-5.

30. Onoyama S, Ogata R, Wada A, Saito M, Okada K, Harada T. Neonatal bacterial meningitis caused by Streptococcus gallolyticus subsp. pasteurianus. J Med Microbiol. 2009;58(Pt 9):1252-4.

31. Li M, Cai C, Chen J, Cheng C, Cheng G, Hu X, Liu C. Inducible Expression of both ermB and ermT Conferred High Macrolide Resistance in Streptococcus gallolyticus subsp. pasteurianus Isolates in China. Int J Mol Sci. 2016;17(10). https://doi.org/10.3390/ijms17101599.

32. Leclerca R, Huet C, Picherot M, Trieu-Cuot P, Poyart C. Genetic basis of antibiotic resistance in clinical isolates of Streptococcus gallolyticus (Streptococcus bovis). Antimicrob Agents Chemother. 2005;49(4):1646-8.

\section{Publisher's Note}

Springer Nature remains neutral with regard to jurisdictional claims in published maps and institutional affiliations.

Ready to submit your research? Choose BMC and benefit from:

- fast, convenient online submission

- thorough peer review by experienced researchers in your field

- rapid publication on acceptance

- support for research data, including large and complex data types

- gold Open Access which fosters wider collaboration and increased citations

- maximum visibility for your research: over $100 \mathrm{M}$ website views per year

At $\mathrm{BMC}$, research is always in progress.

Learn more biomedcentral.com/submissions 